\title{
Science Education: An Overview for Central America
}

\section{Mario Contreras}

\section{Introduction}

CENTRA L A MER I CA G A I NED independence from Spain in 1821. It took a century for the countries to gain some measure of stability and establish the framework for becoming more modern states. Regional cultural roots go back to pre-Columbian civilizations, but economic growth and modernization only began at the middle of this century.

Rapid population growth is a major factor impinging on education and other sectors. The Central American population in 1900 was 4 million; it reached 7 million by 1940 and increased to 25 million by 1990. Projections are that by the year 2010 it will be close to 50 million if current population growth rates of about 2.8 percent per year continue.

Central banking, development of roads and other transportation facilities, small industries, and services were organized or expanded until the 1940s. Governmental research and agricultural extension services began in the mid-1950s. At the time, the Central American population was about 10 million, mostly settled on the pacific slopes and plains, with a few small cities in which were concentrated education, services, and political decision making. In a certain way, the region is relatively young and has been slow to modernize and develop.

Central America comprises a territory of 424,222 km. Individual countries present annual Gross National Products (GNP) ranging from US\$ 1,889 million in Nicaragua to US\$ 9,719 million for Guatemala. Regional Per Capita Income 'averaged US\$1,060 in 1995, but it ranges from US\$ 330 in Nicaragua to US\$2,010 in Costa Rica. Generally speaking, these are small countries in size and national economies.

Economic activity in the region has evolved largely based on agriculture. In consequence, scientific research and technologies have primarily focused on production activities, often carried out by 
transnationals, for export commodities and nontraditional crops. Bananas and coffee are crops that have been researched since early in the century. Modern agricultural technologies coexist, often side by side, with those arising from indigenous practices and innovations. Thus, some of the world's highest yields and best-quality bananas and coffee are from Central America. These crops are supported by sophisticated research and marketing systems. At the same time, smoke from slash-and-burn agriculture, based on pre-Columbian production technologies, cloud the skies of Honduras annually during the dry season. Food, textile, and other light manufacturing industries have also developed based on technologies adapted or transplanted to the region. Original and applied industrial research is scarce and focused toward product transformation.

Central America is a net importer of scientific knowledge and technical know-how. A few good quality research and education programs exist in the region. They focus on agriculture and natural resources management. National research systems are generally weak.

Most of Central America endured considerable social turmoil during the early decades and latter part of this century. Caught in the middle of cold war politics, the region has until recently been ideologically divided, socially disrupted and economically deprived of effective economic and social progress. With the exception of Costa Rica, investment in education has been low, with high rates of illiteracy prevailing in most countries, particularly in rural areas and among ethnic groups. This factor is considered in more detail later.

Current international economic and political conditions are forcing the region into a global environment that demands, above all, human capital resources of the highest quality possible at all levels. Scientific and technical knowledge is increasingly perceived in the region as a strategic resource essential for development. Education is often touted as the road to progress.

Organization of Science Education

All countries in the region have developed formal educational Systems, with administrative structures, academic programs, and national accreditation systems to which public and private domestic 
schools ascribe. Primary, secondary, and vocational education generally fall within the regulatory domain of the government through the Ministries of Education. Postsecondary education is normally regulated by special academic bodies or councils, composed of representatives from public and private colleges and universities. These bodies or councils are largely independent from the public sector, but in some countries are still dominated by the state universities.

Education is organized in a manner similar to that of most countries in the Western Hemisphere. School levels progress from nursery (one year), kindergarten (one year), elementary (six to eight years), secondary (four to six years) to technical (two to three years) or college education (four to five years for a bachelor's degree). Graduate education is variable but usually takes an additional two to three years to complete a master's degree. Doctoral degrees are awarded in a few fields, mostly in administration and in collaboration with universities from more developed nations.

Students can choose at the secondary school level to prepare themselves for eventual professional careers in teaching, administration, or a science. Those pursuing professional careers in fields such as medicine, agriculture, and engineering must take basic courses in biology, chemistry, and physics as part of their high school curriculum. Mathematics is required for all college fields, High school graduates enroll in colleges directly or through an entrance exam.

There is great variability in the quality of education among countries, and between urban and rural areas, and public and private schools. Two major factors are involved: resources available to the schools and management.

\section{A. The Public School System}

The regional public school systems, including colleges and universities, suffer from scarce resources and chronic administrative problems. Science-oriented disciplines are generally more costly to operate and tend to suffer the most from insufficient financial support. Library and laboratory infrastructure are often of poor quality and have limited resources and equipment. Linkages with the international academic and scientific community are weak. Faculty often work only 
part-time at teaching, which tends to be informative and memoristic, rather than participatory and inquisitive.

\section{B. The Private School System}

In general, private education has better quality at all levels. Most of the larger urban centers have bilingual elementary and high schools and their graduates often successfully pursue college degrees abroad.

Contrary to most public universities, private colleges and universities have emerged in significant numbers only in the last two decades. The Pan American School of Agriculture in Honduras, also known as Zamorano, is one of the oldest private colleges in the region and was founded in 1942 (5). Many of the new colleges concentrate on the fields of business administration and economics. In addition to the high demand for education, in these fields, they require relatively modest start-up costs. There also are private colleges offering baccalaureate programs in a variety of technological fields such as mechanical, electrical, computer programming, and similar engineering fields. Industry, commerce, and service industries are fastgrowing economic sectors, with much demand for professionals. Thus, private colleges and universities are responding to perceived economic demands and opportunities for their graduates.

\section{Traditional Science}

Central American rural communities have developed a body of knowledge from observation, trial and error, and experimentation. Information is passed from generation to generation, verbally and through "'demonstration. This type of knowledge has been largely neglected or seen as "scientific" and unreliable.

Participatory approaches to development have shown that rural populations in particular possess an extensive body of knowledge and seek permanent innovation. This is particularly the case for knowledge applied to crop production systems (1).

In Honduras, farmers manage a terminology descriptive of most plant and animal species visible to the naked eye. Important species are differentiated at a level equivalent to that of conventional plant and 
animal taxonomy. Ecological niches and uses for the more important species are fairly well understood. Biological cycles in insects and other small animals tend to be less well understood (4). When provided with microscopes and a proper orientation, however, farmers readily perceive morphological differences, relate behavior to environmental conditions and associate effects on their crops to the activity of microorganisms, such as fungi, bacteria, and nematodes (8).

The cultivation of maize and field beans originated in Mesoamerica and they have been grown in the region for many centuries. Farmer selection over many generations has resulted in local races and varieties adapting to specific agroecological conditions such as pests, storage, cooking, and the taste preferences of the rural families. For instance, Guatemalan farmer-selected maize varieties can be so site specific that their yield is significantly lower when planted at elevations different only a few hundred meters from that of their original sites. Varietal improvement is achieved in these crops more efficiently, when indigenous knowledge and gerplasm are incorporated into modern crop breeding and improvement programs.

Use of medicinal plants to treat different ailments in rural communities and urban centers is extensive in the region. Select plant species have been used for generations to treat wounds, parasites, respiratory ailments, and other common diseases. Medicinal plants are also used for treating more complicated problems, such as kidney stones, hepatitis, and more benign forms of skin cancer. Although there is some disbelief in this practice, many plant species are successfully used for medicinal purposes by a large segment of the population in the region. On the one hand, this is in accord with traditional knowledge and serves a social need for better health. On the other hand, the relatively high cost of imported pharmaceuticals make synthetic medicines unavailable to the rural and urban poor.

With less than 2 percent of the total land surface in the world Central America has around 10 percent of its biological diversity. Unfortunately, potentially useful food, fiber, and medicinal resources are being destroyed at a very high rate (10). Moreover, traditional knowledge is also being lost.

Pharmaceutical companies systematically research indigenous knowledge on medicinal plant and animal species. Often without 
immediate or eventual gain to the people that provide the knowledge. Recently, the National Biodiversity Institute of Costa Rica (INBio) launched a program to inventory the estimated 500,000 flora and fauna in that country (7). The program is partially supported in a joint venture by the Merck Company, which evaluates select species for medicinal, cosmetic and other chemical properties with marketing potential.

A part of the revenues from the eventual sale by Merck of products derived from these species will be shared with INBIO and Costa Rica. This is a very innovative example of an alliance between a small country and a major foreign corporation that promotes learning more about biological diversity and generating financial resources for its conservation.

\section{Obstacles to Science Education}

Science education faces several limitations in the region. Some are directly associated to the larger economic and social environments and cannot be dealt with by educators and scientists alone. Among these limitations are:

\section{Illiteracy}

A fundamental obstacle to higher education in general is the high rate of illiteracy still prevalent in most countries in Central America. Illiteracy averages 26 percent regionally. Costa Rica has a relatively low illiteracy rate 7\%, Honduras has one of 3296' and Guatemala's is still higher. Illiteracy is very prevalent among rural and ethnic populations. Although public investment in elementary education has increased in the last decade, emphasis has mostly been placed on increasing enrollment and coverage. Quality of education remains a fundamental problem. Science education should improve in the measure that basic education improves.

Low Quality of Basic Education 
Attrition rates in college level education are high. In Honduras, only about 30 percent of those enrolling in public universities finish a baccalaureate degree. This often is the result of poor high school preparation in mathematics, physics, chemistry and biology. At Zamorano, overall student attrition is about 20 percent and occurs mostly in the first year of studies. A staggering 16 percent of all attrition is due to poor high school preparation in those subjects (2).

Another way of illustrating the limitations of high school education in the region are the results of college entrance examinations. Zamorano is a private international agricultural college that requires that prospective students pass an entrance examination. The institution has several decades of experience in carrying out such exams throughout Latin America. The exam has been developed by Zamorano and is applied annually by trained faculty to applicants from fifteen countries. The exam places emphasis on high school level mathematics, chemistry, and biology.

Zamorano statistics show a pervasive weakness in these basic subjects among high school graduates from Central America. From the seventeen hundred yearly applicants only about six hundred pass the entrance exam. From these, the top 250 applicants make up the new freshman class. Minimum passing score is 40, with top applicants scoring above 80 percent. As can be seen in Table 1, average scores are below the passing figure.

TABLE 3.

Zamorano Entrance Exam Test Scores for the Bask Sciences for Applicants from Central America

\begin{tabular}{lccc}
\hline & Mathematics & Chemistry & Biology \\
\hline Nicaragua & $28 \%$ & $36 \%$ & $49 \%$ \\
\hline Guatemala & 31 & 36 & 39 \\
\hline Honduras & 38 & 36 & 49 \\
\hline El Salvador & 38 & 44 & 63 \\
\hline Costa Rica & 46 & 47 & 63 \\
\hline AVERAGE & 36 & 40 & 53 \\
\hline
\end{tabular}

Note: Information based on 705 applicants, 1995

Source: Admissions Office, Zamorano, Honduras, 1995. 
The above information also illustrates general differences among subjects and countries. Mathematics consistently stands out as the subject with the lowest scores. There also are differences between rural and urban areas with applicants from rural areas consistently scoring below those from larger cities.

\section{Economic Support and Employment Opportunities}

Including the more established fields of economic importance, such as agriculture, public and private support for science in general is still low. Employment opportunities in technical fields are growing in industry and services, but demand for scientists remains relatively small. Private nonprofit organizations dedicated to scientific research and development are few.

A good example in the region is the Honduran Foundation for Agricultural Research (FHIA), founded on the former Tropical Research Center facilities of the United Fruit Company in $1984(3,6)$. The Agronomic Center for Tropical Research and Education (CATIE) in Costa Rica and Zamorano in Honduras are well-established regional centers that combine education and science applied to development,

Many Central American scientists have administrative positions with international organizations or are pursuing a scientific career in a developed nation. The truth is that science education can hardly flourish $\mathrm{r}$ conditions of poverty and social unrest.

\section{Science and Society}

Science has yet to carve a social niche in the region. Science might be respected, not necessarily understood, and certainly poorly supported financially. Basic knowledge is of little interest. Hence, investment in science tends to be shortsighted and applied to solving pressing problems. On the other hand, scientists as a group have kept a low profile, which does little to enhance the image and recognition of the contributions of science in the region. The role of science needs to be better articulated to society.

State and religion have officially been separate in the Central American countries since the liberal reforms that took place during the 
last century. Creation and evolution are often taught under the same school roof. There is no religious fundamentalism or scientific materialism imposed on education. Some of the best schools in the region have been founded and are operated by religious groups, particularly at elementary and secondary levels. Access to such schools is unrestricted on religious grounds.

\section{The Future of Science Education}

Until recently, the region was subjected very directly to the strife of the larger cold war scenario. Nicaragua and El Salvador suffered fullfledged civil wars that lasted for years and caused enormous social damage. Political violence has also plagued Guatemala for several decades. Foreign investment in the region has been relatively low, while local capital has fled to other countries. Economic growth during this period was largely stymied for a whole generation.

Present global and regional politics and economic strategies highlight the need for qualified human resources at all levels. Public investment in basic education and technical training is on the rise in the region. Public universities, however, are confronting shrinking budgets as governments go through severe fiscal adjustments. Private colleges, on the other hand, have increased in numbers in the last ten years (9).

Under current global economic trends, small nations must be able to participate in regional and international markets and compete effectively (2). Demand for science and technology education should grow vigorously in the perceivable future. Development aid is also paying increasing attention to education. Moreover, telecommunications are improving and, by the end of the century, the region should be well interconnected with the global scientific community. The level of success with which Central America improves education and develops its scientific base will greatly influence its economic growth, its social environment, and the conservation of its natural resources. 
Mario Conteras

References

Chambers R., A. Pacey and L. A. Thrupp. 1990. Farmer Fïst: Farmer Innovation and Agricultural Research. Intermediate Technology Publications, London, 219 pp.

Contreras, M. R. 1995. La evaluación curricular: El caso de Zamorano. Ceiba, Vol. 37, No. 1, pp. 65-75. Zamorano, Honduras.

Contreras, M. R. 1991. Agricultural Research in Honduras: The Organization of a Small-Country Agricultural research system with broad research demands: Institutional diversity in Honduras. Small-Countries Study Paper \#4, ISNAR. The Hague, The Netherlands, $46 \mathrm{pp}$.

Bentley, J. W. 1989. What Farmers Don't Know Can't Help Them: The Strengths and Weaknesses of Indigenous Technical Knowledge in Honduras. Agriculture and Human Values. 6(3): 25-31.

Escuela Agrícola Panamericana. 1994. Informe Anual. Zamorano, Honduras. 79 no.

Fundación Hondureña de Investigación Agrícola. 1994. Informe Anual. La Lima, Honduras. 57 pp.

IMBIO. 1994. Personal Communication. San Jose, Costa Rica.

Sherwood, S. G. 1995. Mastering Mystery: Learning to Manage Plant Diseases with Farmers of Honduras and Nicaragua. MPS Thesis, Cornell University, Ithaca, N.Y.

The World Bank. 1994. Higher Education: The Lessons from Experience. Development in Practice Series, 105 pp., Washington, D.C.

Wilson, E. 1992. The Diversity of Life. W. W. Norton Co., New York. 424 no. 